\title{
CORRELATION BETWEEN DILATATION OF THE BILE DUCTS AND OXIDATIVE STRESS IN PATIENTS WITH CHOLEDOCHOLITHIASIS
}

\author{
Zoran Damnjanović1, Milan Jovanović1,2, Milan Radojković2,3, Dušan Sokolović2, \\ Aleksandar Karanikolić2,4, Nebojša Ignjatović2,3, Nemanja Stepanović ${ }^{1}$, \\ Goran Damnjanovićs, Marko Gmijović ${ }^{3}$
}

\begin{abstract}
The aim of this study was to examine the relationship of inflammatory parameters, lipid peroxidation and oxidative modification of proteins with ultrasound findings of biliary tract in patients with choledocholithiasis. The study included 70 subjects divided into two groups: the choledocholithiasis group (CHDL)-40 patients with obstructive jaundice caused by choledocholithiasis and the control group-30 healthy individuals. All the patients were anamnestically and clinically observed at the Internal Department of Military Hospital in Niš, Serbia.

The values of MDA were not significantly correlated with the degree of dilatation of intrahepatic and extrahepatic bile ducts, while the values of carbonyl groups showed a significant correlation with the degree of dilatation of intrahepatic bile ducts $(p<0.05)$. Dilatation of bile ducts was not significantly associated with inflammation and lipid peroxidation, however, oxidative modification of the protein showed a significant positive correlation with dilatation of the intrahepatic bile ducts.
\end{abstract}

Acta Medica Medianae 2020;59(2):47-52.

Key words: oxidative stress, choledocholithiasis, ultrasound, biliary ducts

\footnotetext{
${ }^{1}$ Vascular Surgery Clinic, Clinical Center of Niš, Serbia

2University of Niš, Faculty of Medicine, Nišs, Serbia

${ }^{3}$ Digestive Surgery Clinic, Clinical Center of Niš, Serbia

${ }^{4}$ Breast and Endocrine Surgery Clinic, Clinical center of Niš, Serbia

${ }^{5}$ Department of Internal Medicine, Military Hospital of Nišs, Serbia
}

Contact: Zoran Damnjanović

48 Dr. Zoran Djindjić Blvd., 18000 Niš, Serbia

E-mail: damnjanovicz@yahoo.com

\section{Introduction}

Procedures used in the morphological diagnosis of extrahepatic caused obstructive jaundice are: ultrasonography (US), computed tomography (CT), magnetic resonance (NMR) and magnetic cholangiography (MRCP). Direct visualization of the biliary tract, either with cholangiopancreatography (ERCP) or percutaneous transhepatic cholangiography (PTC) is still the gold standard in the presentation of the biliary tract (1). Ultrasound as the cheapest, safest and most sensitive technique for displaying hepatobiliary-pancreatic system represents an ideal screening method. This method is valid for discovering the cause of extrahepatic cholestasis in a wide variety of etiological cause. Extrahepatic obstruction suggests a dilatation of extrahepatic bile ducts, but displaying normal extrahepatic bile ducts cannot totally exclude the presence of obstruction (2).

Inflammation, cholestasis and oxidative stress are following disorders of choledocholithiasis (3-5). Previous studies in patients with choledocholithiasis showed a positive correlation between the number of monocytes and the activities of aspartate transaminase (AST), hyperbilirubinemia, and fibrinogen and albumin and alanine transaminase (ALT), while a negative correlation was observed between albumin and alkaline phosphatase (AP) (6). Significant positive correlation between the total, direct and indirect bilirubin with oxidative modification of proteins was proven, whereas neutrophils and the levels of total, direct and indirect bilirubin evaluation showed a significant positive correlation with lipid peroxidation $(7,8)$.

There are no literature data that show the correlation of the parameters of inflammation and oxidative stress with ultrasound findings of biliary tract in patients with choledocholithiasis. Therefore, the aim of this study was to examine the correlation of inflammatory parameters, lipid peroxidation and oxidative modification of proteins with ultrasound 
findings of biliary tract in patients with choledocholithiasis.

\section{Patients and methods}

The study included 70 subjects divided into two groups: the choledocholithiasis group (CHDL)40 patients with obstructive jaundice caused by choledocholithiasis and the control group-30 healthy individuals.

The patients with extrahepatic cholestasis due to mechanical obstruction caused by choledocholithiasis were included in the study. The obstruction of biliary ducts caused by other factors was not considered.

The diagnosis of obstructive icterus was made according to anamnestic data, clinical features, and biochemical and ultrasound examination of biliary ducts. For the ultrasound examination of biliary ducts in the supine position a Sono et Medison Co. Ltd. ultrasound was used. Based on ultrasound, examination was performed to evaluate the level of bile duct dilatation in two categories: dilatation of extrahepatic bile duct (DEBD) and dilatation of intrahepatic bile ducts (DIBD).

All the patients were anamnestically and clinically observed at the Internal Department of Military Hospital in Niš, Serbia. Basic biochemical indicators and parameters of oxidative stress were determined in Biochemical Laboratory of Military Hospital in Niš and the Laboratory of the Biochemistry Institute of the Faculty of Medicine in Niš.

All the patients with choledocholitiasis were tested in the first three days since the occurrence of cholestasis syndrome and before surgery or endoscopic retrograde cholangiopancreatography (ERCP) with papillotomy.

Participants of both groups did not differ in gender and age structure. Out of the total number of studied subjects, $37(53 \%)$ were men and $33(47 \%)$ women. The average age of the patients was $58.8 \pm$ 15.9 years.

\section{Biochemical analysis}

Inflammatory and cholestatic parameters: activity of $\gamma$-glutamyltransferase ( $\gamma$-GT), alkaline phosphatase, level of total, direct and indirect bilirubin, aspartate aminotransferase, alanine aminotransferase, albumin (Alb), fibrinogen (Fib), C-reactive protein (CRP), leukocytes (Leu), lymphocytes (Ly), monocytes (Mo) and granulocytes (Gr). The previously mentioned biochemical parameters were determined by the ready tests produced by Elitech Company, on the biochemical analyzer BTS-370 (Biosystem).

Assessment of oxidative protein modification products in form of carbonyl groups (CG), was made by using a colorimetric reaction with 2,4-dinitrophenylhydrazine (2,4 DNPH) and TCA (9). Assessment of carbonyl groups in amino acid residue is an im- portant marker of oxidative protein modification. Concentration of carbonyl groups was expressed in $\mu \mathrm{mol} / \mathrm{g}$ plasma protein.

The intensity of lipid peroxidation in the plasma was measured spectrophotometrically, and based on the thiobarbituric response products as described by Ohkawa et al. (10). Malondialdehyde (MDA - lipid peroxidation end product) concentration was expressed as $\mu \mathrm{mol} / \mathrm{l}$, using the MDA molecular absorbance coefficient $\left(1.56 \times 10^{-5} \mathrm{~mol} \mathrm{~cm}^{-1}\right)$.

\section{Statistical analysis}

The data were analyzed by means of the commercially available statistic software package (SPSS ${ }^{\circledR}$ for Windows, v. 9.0, Chicago, USA) using the Student's t-test and Chi-square test. The results were presented as means $\pm / S D$. Statistical significance was set to $p<0.05$. To demonstrate the correlation between the parameters of inflammation and oxidative stress with ultrasound findings of the biliary tract in patients with choledocholithiasis Pearson's correlation coefficient was used ( $r$ ).

\section{Results}

The results of laboratory parameters in control group and patients with choledocholitiasis are shown in Table 1.

Statistically significant difference of albumin $(p<0.001)$ and higher values of fibrinogen $(p<$ $0.05)$ and CRP $(p<0.001)$ were in the group of patients with choledocholithiasis compared to the control group. Higher values of leukocytes $(p<0.01)$ and granulocytes $(p<0.001)$, with a decrease in the number of lymphocytes $(p<0.001)$, and monocytes $(p<0.001)$ were found in the group of patients with choledocholithiasis compared to the control group. Intensity of oxidative protein modification was followed by a change in the levels of carbonyl groups, which were statistically significantly higher in patients with choledocholithiasis $(p<0.001)$ compared to the control group of patients. The values of MDA were significantly increased $(p<0.001)$ in patients with extrahepatic cholestasis caused by choledocholithiasis, compared to the control group.

Correlation between indicators of inflammation and oxidative stress with ultrasound findings of the biliary tract in patients with choledocholithiasis is shown in Table 2.

In patients with choledocholithiasis, dilatation of intra and extrahepatic bile ducts did not significantly correlate with the systemic indicators of inflammation. The values of MDA were not significantly correlated with the degree of dilatation of intrahepatic and extrahepatic bile ducts, while the values of carbonyl groups showed a significant correlation with the degree of dilatation of intrahepatic bile ducts $(p<0.05)$. 
Table 1. The results of laboratory parameters in the control group and patients with choledocholitiasis

\begin{tabular}{|lcc||}
\hline \multicolumn{1}{|c}{ Parameter } & Control & CHDL \\
\hline \hline Albumin $(\mathrm{g} / \mathrm{l})$ & $46.1 \pm 4.3$ & $36.7 \pm 6.6^{* * *}$ \\
Fibrinogen $(\mathrm{g} / \mathrm{l})$ & $3.5 \pm 1.1$ & $5.1 \pm 1.2^{*}$ \\
C-reactive protein $(\mathrm{mg} / \mathrm{dl})$ & $4.7 \pm 1.3$ & $11.2 \pm 7.1^{* * *}$ \\
Leukocytes $(\mathrm{G} / \mathrm{l})$ & $6.1 \pm 1.4$ & $9.9 \pm 6.3 * *$ \\
Lymphocytes $(\%)$ & $28.8 \pm 9.4$ & $15.3 \pm 8.2 * * *$ \\
Monocytes $(\%)$ & $8.5 \pm 3.0$ & $5.2 \pm 3.9 * * *$ \\
Granulocytes $(\%)$ & $62.2 \pm 8.9$ & $79.4 \pm 10.6 * * *$ \\
MDA $(\mu \mathrm{mol} / \mathrm{l})$ & $21.6 \pm 2.0$ & $51.2 \pm 8.6 * * *$ \\
Carbonyl groups $(\mu \mathrm{mol} / \mathrm{g}$ protein) & $5.7 \pm 1.8$ & $8.8 \pm 3.0 * * *$ \\
\hline \hline
\end{tabular}

$* \mathrm{p}<0.05 ; * * \mathrm{p}<0.01 ; * * * \mathrm{p}<0.001$ compared to the controls

Table 2. Correlation between indicators of inflammation and oxidative stress, and ultrasound findings of biliary tract in patients with choledocholithiasis

\begin{tabular}{||lcc||}
\hline \multicolumn{1}{|c}{ Parameter } & DIBD & DEBD \\
\hline \hline Albumin $(\mathrm{g} / \mathrm{l})$ & 0.124 & 0.107 \\
Fibrinogen $(\mathrm{g} / \mathrm{l})$ & -0.239 & -0.247 \\
C-reactive protein $(\mathrm{mg} / \mathrm{dl})$ & 0.162 & -0.041 \\
Leukocytes $(\mathrm{G} / \mathrm{l})$ & -0.353 & 0.072 \\
Lymphocytes $(\%)$ & 0.176 & -0.011 \\
Monocytes $(\%)$ & 0.165 & -0.017 \\
Granulocytes $(\%)$ & -0.201 & 0.008 \\
MDA $(\mu \mathrm{mol} / \mathrm{l})$ & -0.15 & 0.01 \\
Carbonyl groups $(\mu \mathrm{mol} / \mathrm{g}$ protein) & $0.4 *$ & 0.11 \\
\hline
\end{tabular}

$*_{p}<0.05$

\section{Discussion}

In patients with obstructive jaundice, ultrasonography is the first and widely accepted method for displaying dilated intrahepatic bile ducts. Ultrasonography is very reliable in detecting the level of obstruction, and in most cases is able to identify the reason of obstruction (11). Recent years have developed new methods in the review of patients with diseases of the gall bladder and bile ducts. One of them is intraoperative ultrasonography, which can clearly see the invasion of the gallbladder and associated blood vessels in the case of tumors, and define the difference between intraluminal and extra luminal tumors (12). Lipid peroxidation of unsaturated fatty acids associated with free radicals is adverse and negative process that leads to the damage of lipid membranes of cells. It may disrupt the regulation of membrane fluidity and permeability of the plasma membrane of hepatocytes (13). Lipid peroxidation products such as hydro peroxides of unsaturated fatty acids, short chain hydrocarbons and aldehydes (MDA), possess a pronounced cytotoxic effect (14). MDA toxicity is based on its ability to act as a mutagenic agent is in a cell (15).

Oxidative modification of the protein and amino acids by free radicals is caused by the reaction of the side chains of amino acid residues of their 
breaking away, or the fragmentation of the protein in the conversion of higher molecular form (16). The degree and type of oxidative damage, and therefore the consequences, depend on the affinity of free radicals to certain classes of biomolecules. In particular, the oxidations of sensitive amino acids are methionine and cysteine. As the largest oxidation number of mechanisms leading to the formation of carbonyl group, and this group is most often used as a marker of oxidative damage to proteins (17).

Due to these characteristics of oxidative stress markers, the objective of this study was to determine the correlation of MDA and carbonyl groups with ultrasound findings of dilatation of the bile ducts. The fact is that we have developed many methods for determining these parameters of oxidative stress, which does not require special and expensive equipment and can be implemented in standard-equipped laboratories, and the determination of their serum levels could be part of routine biochemical diagnostic algorithm in patients with choledocholithiasis (18).

Results of the research showed that the dilatation of intrahepatic and extrahepatic bile ducts did not significantly correlate with the systemic indicators of inflammation in the blood plasma. Also, the results of our study did not show a clear correlation between the values of the parameters of oxidative stress, and degree of dilatation of the biliary tree. Higher values $(p<0.05)$ of carbonyl groups in pa- tients with dilatation of intrahepatic bile ducts were statistically significant. Possible explanation of this finding is persistent cholestasis in these patients, which led to the complete dilatation of the biliary tree and the consequent damage or oxidative stress of hepatocytes, which resulted in the increased production of carbonyl groups.

Dilatation of only extrahepatic bile ducts in the initial stage of biliary obstruction is likely still not enough for functional impairment of the liver parenchyma in the direction of oxidative stress. Also, because of its specificity, determining MDA and carbonyl groups could be useful in detecting and determining the intensity of eventually present cholangitis in patients with choledocholithiasis. This finding points to the importance of the earliest possible resolution of cholestasis in order to prevent parenchymal damage or justification for timely preventive hepatoprotective therapy.

\section{Conclusion}

In patients with choledocholithiasis, ultrasound diagnosis of dilatation of bile ducts was not significantly associated with inflammation and lipid peroxidation, however, oxidative modification of the protein showed a significant positive correlation with dilatation of the intrahepatic bile ducts. 


\section{References}

1. Sharma MP, Ahuja V. Aetiological spectrum of obstructtive jaundice and diagnostic ability of ultrasonography: a clinician's perspective. Trop Gastroenterol 1999; 20(4):167-9. [PubMed]

2. Donev S. About some clinical ultrasound and endoscopic difficultes in the diagnoses of choledocholitiasis. Khirurgiia 2005; (4-5):48-50. [CrossRef] [PubMed]

3. Li Z, Zhang Z, Hu W, Liu X, Mai G, Zhang Y, et al. Pancreaticoduodenectomy with preoperative obstructtive jaundice: drainage or not. Pancreas 2009; 38(4): 379-86. [CrossRef] [PubMed]

4. Copple $B L$, Jaeschke $H$, Klaassen $C D$. Oxidative stress and the pathogenesis of cholestasis. Semin Liver Dis 2010;30(2):195-204. [CrossRef] [PubMed]

5. Damnjanović Z, Nagorni A, Kocić G, Blagojević Z, Mančić $Đ$, Damnjanović I. Follow-up of biochemical parameters and intensity of oxidative stress in patients with extrahepatic cholestasis. Acta Medica Medianae 2008;47(3):21-7.

6. Damnjanović $Z$, Jovanović $M$, Nagorni $A$, Sokolović $D$, Đinđić $B$, Damnjanović $G$ et al. Correlation between inflammatory parameters and markers of cholestasis on patients with choledocholitiasis. Acta Medica Medianae 2014;53(2):28-32. [CrossRef]

7. Damnjanović $Z$, Jovanović $M$, Nagorni $A$, Sokolović $D$, Radojković M, Damnjanović G et al. Connection between markers of cholestasis and intensity of oxidative modification of proteins in patients with choledocholitiasis. Acta Medica Medianae 2014;53(1): 10-4. [CrossRef]

8. Damnjanović $Z$, Jovanović M, Nagorni A, Radojković $M$, Sokolović $D$, Damnjanović $G$ et al. Interrelation between inflammation parameters and biochemical markers of cholestasis with intensity of lipid peroxidation in patients with choledocholithiasis. Vojnosanit Pregl 2013;70(2):170-6.

[CrossRef] [PubMed]
9. Levine RL, Williams JA, Stadtman ER, Shacter E. Carbonyl assays for determination of oxidatively modified proteins. Methods Enzymol 1994;233:346-57. [CrossRef] [PubMed]

10. Ohkawa H, Ohishi N, Yagi KL. Assay for lipid peroxides in animal tissues by thiobarbituric acid reaction. Anal Biochem 1979; (95):351-8. [CrossRef] [PubMed]

11. Wills M, Harvey CJ, Kuzmich S, Afaq A, Cosgrove D. Ultrasound of the gall bladder and biliary tree: part 1 . Br J Hosp Med 2014;75(6):312-7. [CrossRef] [PubMed]

12. Cirimbei S, Puşcu C, Lucenco L, Brătucu E. The role of intraoperative ultrasound in establishing the surgical strategy regarding hepato-bilio-pancreatic pathology. Chirurgia 2013;108(5):643-51. [PubMed]

13. Ramana KV, Srivastava S, Singhal SS. Lipid peroxidation products in human health and disease 2014. Oxid Med Cell Longev 2014; 2014: 162414. [CrossRef] [PubMed]

14. Ayala $A$, Muñoz MF, Argüelles S. Lipid peroxidation: production, metabolism, and signaling mechanisms of malondialdehyde and 4-hydroxy-2-nonenal. Oxid Med Cell Longev 2014;2014: 360438. [CrossRef] [PubMed]

15. Assimakopoulos SF, Thomopoulos KC, Patsoukis N, Georgiou CD, Scopa CD, Nikolopoulou VN, Vagianos $\mathrm{CE}$. Evidence for intestinal oxidative stress in patients with obstructive jaundice. Eur J Clin Invest 2006; 36(3):181-7. [CrossRef] [PubMed]

16. Berlett BS, Stadtman ER. Protein oxidation in aging, disease, and oxidative stress. J Biol Chem 1997; 272 (33):20313-6. [CrossRef] [PubMed]

17. Beal MF. Oxidatively modified proteins in aging and disease. Free Radic Biol Med 2002;32(9):797-803. [CrossRef] [PubMed]

18. Dalle-Donne I, Rossi R, Giustarini D, Milzani A, Colombo R. Protein carbonyl groups as biomarkers of oxidative stress. Clin Chim Acta 2003; 329(1-2):2338. [CrossRef] [PubMed] 


\title{
POVEZANOST DILATACIJE ŽUČNIH PUTEVA I OKSIDATIVNOG STRESA KOD BOLESNIKA SA HOLEDOHOLITIJAZOM
}

\author{
Zoran Damnjanović1, Milan Jovanović1,2, Milan Radojković2,3, Dušan Sokolović2, \\ Aleksandar Karanikolić2 ${ }^{2,4}$, Nebojša Ignjatović2,3, Nemanja Stepanović ${ }^{1}$, \\ Goran Damnjanovićs, Marko Gmijović3
}

\author{
${ }^{1}$ Klinika za vaskularnu hirurgiju, Klinički centar Niš, Niš, Srbija \\ 2Univerzitet u Nišu, Medicinski fakultet, Niš, Srbija \\ ${ }^{3}$ Klinika za digestivnu hirurgiju, Klinički centar Niš, Niš, Srbija \\ ${ }^{4}$ Klinika za endokrinu hirurgiju i hirurgiju dojke, Klinički centar Niš, Niš, Srbija \\ ${ }^{5}$ Odeljenje interne medicine, Vojna bolnica u Nišu, Niš, Srbija
}

Kontakt: Zoran Damnjanović

Bulevar dr Zorana Đinđića 48, 18000 Niš, Srbija

E-mail: damnjanovicz@yahoo.com

Cilj ovog istraživanja bilo je ispitati povezanost inflamatornih parametara lipidne peroksidacije i oksidativne modifikacije proteina sa ultrazvučnim nalazom bilijarnog trakta kod bolesnika sa holedoholitijazom. Istraživanje je obuhvatilo 70 ispitanika podeljenih u dve grupe: grupa bolesnika sa holedoholitijazom (CHDL) - 40 bolesnika sa opstruktivnom žuticom, izazvanom holedoholitijazom; i kontrola grupa - 30 zdravih dobrovoljaca. Svi bolesnici su anamnestički i klinički sagledani na Internom odeljenju Vojne Bolnice u Nišu (Srbija). Vrednost MDA nisu bile značajno povezane sa stepenom dilatacije intrahepatičnih i ekstrahepatičnih žučnih puteva, dok su vrednosti karbonilnih grupa pokazale značajnu korelaciju sa stepenom dilatacije intrahepatičnih puteva $(p<0,05)$. Dilatacija žučnih puteva nije bila značajno povezana sa inflamacijom i lipidnom peroksidacijom, dok je oksidativna modifikacija proteina pokazala značajnu pozitivnu povezanost sa dilatacijom intrahepatičnih žučnih puteva.

Acta Medica Medianae 2020;59(2):47-52.

Ključne reči: oksidativni stres, holedoholitijaza, ultrazvuk, žučni kanali 